\title{
Profile of Scientific and Technological Production in Nursing Education Research Groups in the South of Brazil
}

\author{
Mônica Motta Lino ${ }^{1}$ \\ Vânia Marli Schubert Backes² \\ Bruna Pedroso Canever ${ }^{3}$ \\ Fabiane Ferraz ${ }^{4}$ \\ Marta Lenise Prado 5
}

\begin{abstract}
This research aimed to present the profile of production of Nursing Education Research Groups' (NERG) scientific and technological production in the South of Brazil. This documentary, quantitative, exploratory-descriptive retrospective research was guided by the active search for products in the Lattes curriculum of previously selected NERG researchers, based on the 2006 Census of the Research Group Directory/CNPq, between 1995 and 2008. The results indicated that the 18 NERG from southern Brazil produced 453 papers in proceedings, 371 book chapters, 206 books, 1,437 scientific articles and 08 technological products, but no patent was registered. NERG's scientific production in the research region has grown progressively over the past 14 years. To strengthen this structure, the establishment of collaborative networks can be used as a strategy, so that political-scientific joint actions in the sector can advance science and technology.
\end{abstract}

Descriptors: Nursing; Nursing Education Research; Publications for Science Diffusion; Education; Nursing; Educational Technology.

Universidade Federal de Santa Catarina, SC, Brazil:

${ }^{1}$ RN, Master's Student, Nursing Graduate Program, Scholarship holder CNPq. E-mail: monicafloripa@hotmail.com.

${ }^{2}$ RN, Ph.D. in Nursing, Associate Professor, Departamento de Enfermagem. E-mail: oivania@ccs.ufsc.br.

${ }^{3}$ Nursing undergraduate student, Scholarship holder PIBIC/CNPq. E-mail: olabruna@gmail.com.

${ }^{4}$ RN, Doctoral Student, Nursing Graduate Program. E-mail: olaferraz@yahoo.com.br.

${ }^{5}$ RN, Ph.D. in Nursing, Adjunct Professor. E-mail: mpradop@ccs.ufsc.br.

Corresponding Author:

Mônica Motta Lino

Universidade Federal de Santa Catarina

Campus Universitário

Bairro Trindade

CEP: 88040-970 Florianópolis, SC, Brasil

E-mail: monicafloripa@hotmail.com 


\section{Perfil da produção científica e tecnológica dos grupos de pesquisa em educação em enfermagem da Região Sul do Brasil}

O objetivo do estudo foi apresentar o perfil da produção científica e tecnológica dos Grupos de Pesquisa em Educação em Enfermagem (GPEE) da Região Sul do Brasil. Trata-se de pesquisa documental, quantitativa, exploratório-descritiva retrospectiva, guiada pela busca ativa das produções no Currículo Lattes dos pesquisadores dos GPEE pré-selecionados, a partir do Censo-2006 do Diretório de Grupos/CNPq, no período de 1995-2008. Os resultados indicaram que os 18 GPEE do Sul do Brasil produziram 453 trabalhos em anais, 371 capítulos de livros, 206 livros, 1437 artigos científicos e 8 produtos tecnológicos, porém, nenhuma patente registrada. A produção científica dos GPEE da Região investigada vem crescendo progressivamente nos últimos 14 anos. Para que essa estrutura seja fortalecida, pode-se utilizar como estratégia a formação de redes colaborativas que viabilizem articulações político-científicas no setor para avançar em ciência e tecnologia.

Descritores: Enfermagem; Pesquisa em Educação de Enfermagem; Publicações de Divulgação Científica; Educação em Enfermagem; Tecnologia Educacional.

\section{Perfil de la producción científica y tecnológica de los grupos de investigación en educación en enfermería de la región Sur de Brasil}

El objetivo del estudio fue presentar el perfil de la producción científica y tecnológica de los Grupos de Investigación en Educación en Enfermería (GIEE) de la región sur de Brasil. Se trata de una investigación documental, cuantitativa, exploratoria-descriptiva retrospectiva, guiada por la búsqueda activa de las producciones, en el Currículo Lattes, de los investigadores de los GIEE, preseleccionados a partir del Censo-2006 del Directorio de Grupos/CNPq, en el período de 1995-2008. Los resultados indicaron que los 18 GIEE del sur de Brasil produjeron 453 trabajos en anales, 371 capítulos de libros, 206 libros, 1437 artículos científicos y 8 productos tecnológicos, sin embargo, ninguna patente registrada. La producción científica de los GIEE de la Región investigada viene creciendo, progresivamente, en los últimos 14 años. Para que esa estructura sea fortalecida, se puede utilizar como estrategia la formación de redes colaborativas que viabilicen articulaciones político-científicas en el sector para avanzar en ciencia y tecnología.

Descriptores: Enfermería; Investigación en Educación de Enfermería; Publicaciones de Divulgación Científica; Educación en Enfermería; Tecnología Educacional.

\section{Introduction}

Advances in scientific and technological development are fundamental for a country's growth. In this context, since the 1970's, as a part of the greater health area, graduate programs in Nursing have driven the development of researchers and research actions and served as protagonists in knowledge construction, continuously followed and assessed by the Coordination for the Improvement of Higher Education Personnel (CAPES) $^{(1)}$.

This is no different in the Nursing Education sector. The search for excellence in scientific productions is constant, due to its importance and need for formal education, popular education, permanent education in health, educational technologies and, likewise, for human wellbeing. Moreover, productive capacity reveals to be the center of funding and assessment entities' attention and frequently arouses discussion among members of Nursing Education Research Groups (NERG). Science and technology production has evolved with a view to concrete needs that emerge in health professionals' daily practice and, based on its products, can provoke changes in different structures' work processes. In this sense, scientific activity can be measured by scientific paper production statistics, whie technological production can 
be measured by the innovation system, reflecting in the registration of patents ${ }^{(2)}$. For the Nursing Education sector, technology can be reflected by educational technology, considered as "a systematic set of scientific knowledge that permit the planning, execution, control and follow-up of the entire formal and informal education process"(3).

To understand the range of this sector, in 2006, 331 Nursing Research Groups existed in Brazil, 75 of which in the South. Specifically in that region, 18 Research Groups in Nursing Education (NERG) are registered, identified by the word "education/teaching/formation" in the Group's name. Seven of these come from Paraná State, three from Santa Catarina and eight from Rio Grande do Sul. In these NERG, 173 researchers are registered, 77 in Paraná, 25 in Santa Catarina and 71 in Rio Grande do Sul. A large majority comes from the Nursing area and only nine from other knowledge areas. With regard to education, $86 \%$ of the researchers have M.Sc. and Ph.D. degrees and 49\% hold an education degree, among others ${ }^{(4)}$.

Considering the number of NERG in the South of Brazil, as well as the peculiarities of their constitution and range, the production developed in this context should be examined. Thus, this research responds to the following guiding question: what is the profile of Nursing Education Research Groups' scientific and technological production in the South of Brazil?

Picturing the panorama of scientific and technological production allows the NERG and their peers to recognize the productive profile developed within their structures. Moreover, it promotes these Groups' reflection about how they are contributing to the scientific and technological production process in the Nursing Education sector, which can give rise to self-criticism and consequent advances in current productivity rates. In this perspective and with a view to responding to some emerging challenges in Nursing Education, this research aimed to present the profile of Nursing Education Research Groups' scientific and technological production in the South of Brazil.

\section{Method}

This is a documentary, quantitative, exploratorydescriptive retrospective research. Data were collected by searching the Lattes curriculum/CNPq of researchers registered in the NERG, from the South of Brazil, and considered the entire scientific and technological production between 1995 and 2008, that is, production in the five last CAPES three-year assessment periods. The list of 173 researchers was obtained from the CNPq online Portal Base of Data and Statistics - 2006 Census, corresponding to registration data for 2005-2006. That
Census was used as it was the most updated version available in the system at the time of data collection.

The selection of products published by NERG researchers from the South of Brazil included scientific papers, books, book chapters, research published in proceedings and technological products, with or without patents registered by the researchers. Findings were stored in libraries and systemized per publication year, states from the South of Brazil and higher education institution of origin for the sake of further analysis, using the bibliographic management software EndNote ${ }^{\circledR}$. This software automatically presents figures for the production stored in its database and excludes any repeated production due to multiple authorship, permitting further simple statistical analysis of the findings.

As this is a documentary research whose available contents is public, this research was not submitted to the Ethics Committee for Research involving Human Beings. The researchers complied with all ethical recommendations needed for the analysis and dissemination of the research findings.

\section{Results}

Between 1995 and 2008, the NERG from the South of Brazil produced 453 studies published in proceedings, 371 book chapters, 206 books, 1437 scientific articles and eight unpatented technological products. Based on production figures for NERG from the South of Brazil, at this moment, the researchers decided to present results for scientific papers in further detail, considering their specific relevance for the Nursing Education sector (Table 1).

Table 1 - Temporal distribution (1995-2008) of scientific paper production by Nursing Education Research Groups in the South of Brazil. CNPq, 2008

\begin{tabular}{ccccc}
\hline Year & Paraná & Santa Catarina & Rio Grande do Sul & Total \\
\hline 1995 & 14 & 9 & 23 & 46 \\
1996 & 17 & 14 & 18 & 49 \\
1997 & 17 & 22 & 18 & 57 \\
1998 & 14 & 11 & 22 & 47 \\
1999 & 26 & 21 & 23 & 70 \\
2000 & 31 & 37 & 50 & 118 \\
2001 & 22 & 15 & 30 & 67 \\
2002 & 33 & 12 & 47 & 92 \\
2003 & 47 & 23 & 71 & 141 \\
2004 & 35 & 23 & 57 & 115 \\
2005 & 32 & 47 & 70 & 149 \\
2006 & 50 & 34 & 79 & 163 \\
2007 & 46 & 52 & 82 & 180 \\
2008 & 49 & 33 & 61 & 143 \\
\hline Total & 433 & 353 & 651 & 1437 \\
\hline Source: 2006 Census CNPq and Lattes Platform/CNPq, 2008 & \\
& & & &
\end{tabular}


In the last five years (2004-2008), the NERG from the South of Brazil registered the publication of 750 scientific papers, corresponding to $52 \%$ of their scientific paper production in the last 14 years. Two hundred and twelve (212) of these were produced by NERG from Paraná, 189 from Santa Catarina and 349 from Rio Grande do Sul. This result infers an average production of four papers per researcher in the last five years. The distribution of this average changes considerably though when perceived per State: every year, the production vs. researcher ratio is between two and three papers in Paraná, between seven and eight in Santa Catarina and between four and five in Rio Grande do Sul.

Besides the scientific papers' quantitative distribution, the qualification of the journals they were published in was also verified, using the list of scientific dissemination sources called Qualis/CAPES (Table 2). According to this indicator, the strictu sensu graduate programs' intellectual production was classified as follows until the end of 2008: in terms of circulation (Local, National and International), quality $(A, B, C)$ and per knowledge area: Nursing.

Table 2 - Distribution of scientific paper production by Nursing Education Research Groups in the South of Brazil, 2004-2008, according to Qualis/CAPES for the Nursing area. CAPES, 2008

\begin{tabular}{lcccccc}
\hline \multicolumn{1}{c}{ Qualis/CAPES } & $\mathbf{2 0 0 4}$ & $\mathbf{2 0 0 5}$ & $\mathbf{2 0 0 6}$ & $\mathbf{2 0 0 7}$ & $\mathbf{2 0 0 8}$ & Total \\
\hline International A & 1 & - & - & 2 & 3 & 6 \\
International B & 15 & 27 & 38 & 35 & 21 & 136 \\
International C & 34 & 38 & 55 & 75 & 79 & 281 \\
National A & - & - & - & - & 1 & 1 \\
National B & 20 & 24 & 25 & 23 & 16 & 108 \\
National C & 49 & 56 & 22 & 14 & 7 & 148 \\
Not included* & - & - & 23 & 31 & 16 & 70 \\
Total & 119 & 145 & 163 & 180 & 143 & 750 \\
\hline
\end{tabular}

Source: 2006 Census CNPq and Lattes Platform/CNPq, 2008 ${ }^{*}$ Not included in the Qualis list/CAPES

To present the results from the perspective of publication quality, the Qualis-Qualitative Ratio (IQQ) was used, which indicates the proportion of published articles classified as Qualis/CAPES International in relation to the general paper production. The researchers created this ratio in view of the need to measure the proportion of papers in different types of Qualis/CAPES. If the IQQ equals one (1), this means that the entire scientific paper production under analysis circulates internationally, according to Qualis/CAPES.

To calculate the IQQ, the ratio between international products ( $\mathrm{ni}$ ) and total products $(\mathrm{n})$ needs to be calculated, in this case for scientific papers. To give an example: as presented in Table 2, in 2004, 50 articles were published in Qualis/CAPES International (ni) journals, among the 119 papers published during the same period $(n)$. To discover the IQQ, (ni) should be divided by $(n)$, that is: $50 / 119=0.42$. Hence, it can be affirmed that the international scientific papers' IQQ in 2004 was 0.42 , that is, $42 \%$ of papers were published in journals classified as Qualis/CAPES International.

The IQQ permitted a more proper analysis of Table 2. Based on this panorama, the IQQ for the NERG from the South of Brazil was 0.56 during the research period, as follows: 0.48 in Paraná, 0.66 in Santa Catarina and 0.55 in Rio Grande do Sul.

\section{Discussion}

In the 1970's, a movement occurred to stimulate the concentration of graduate programs' efforts in intellectual activities. In this context, the first Nursing Research group was created in Brazil in 1973, called the Study and Research Group on the Elderly - NESP/UFBA, followed by the Study Group on Health Care for Elderly People - GESPI/UFSC, nine years later(5). From 1973 to 2006, a leap was made from one (1) to 331 Nursing Research groups in Brazil, a growth that accompanies the expansion of graduate programs ${ }^{(4)}$.

As from the 1990's, when CAPES was restructured and the focus on the accompaniment and assessment of Brazilian strictu sensu graduate courses was strengthened(6), the quality control of the scientific and academic community is furthered, focused on the preparation and quality of researchers. In this sense, doctoral courses in Nursing stand out, with particular emphasis on productivity(7).

In this Brazilian parameter, scientific products in Nursing are mostly disseminated through presentations at congresses, symposia and scientific meetings, resulting in a small number of publications in scientific journals. Hence, the slow knowledge dissemination can be linked with the choice of the scientific research dissemination channel ${ }^{(5)}$. This reality is different in the Nursing Education sector in the South of Brazil though, considering that, despite the important indicator of full publications in proceedings, in the 14 years under analysis, knowledge dissemination through publications in scientific journals has predominated.

Increasing the national and international visibility of scientific production in Nursing demands, among many factors, competent researchers, a large-scale research 
stimulation policy, the combination of regional efforts and determination to achieve goals. Furthermore, a wider dimension is involved, as the construction process of new knowledge is not sufficient to strengthen the Nursing area. The true challenge imposed on graduate programs is the consumption of these products conceived by their researchers and their applicability in professional practice, benefiting the population based on themes of social interest ${ }^{(1)}$.

Nursing researchers should accompany and measure research impact ratios. In particular, the produced knowledge should be continuously assessed to verify the use and applicability of its results in professional practice. The biggest challenge is to construct experimental research, based on premises of changes in health practices ${ }^{(8-9)}$.

The ratios of the NERG's papers published in Qualis/ CAPES international in the South of Brazil are satisfactory, as illustrates by the IQQ that measures production as a whole. Regional inequities occur in this sense though: Santa Catarina plays a more representative role in scientific production in Nursing Education, considering the quantitative focus and the quality of the journals articles are published in, as most of its articles are published in Qualis International journals. Only NERG from Rio Grande do Sul managed to publish in Qualis International $A$ journals, a target researchers all over the world desire. This finding gives rise to a question: why is it still so hard to publish in Qualis International A journals?

Various scientific studies have announced some important barriers to achieve Nursing publications of international quality, such as the inversion of the educational focus to research, the pure conversion of productivity indicators, insufficient fundings for the science and technology sector in Nursing, nurses' lack of experience as researchers, the need and stress to combine teaching with research, nurses' late contact with scientific research - which can easily be related with the small number of undergraduate students in research groups, and also with the few, disputed and badly distributed scientific initiation grants offered to this group ${ }^{(5-10)}$.

Nursing's pre-professional history itself is marked by women subordinated to knowledge and male hegemony, low remuneration, the prevalent medical power and the strong trend towards biologicism, until it became a profession globally in the 19th century and in Brazil from 1920 onwards. In view of this short history, nowadays, Nursing faces inherited challenges. The search for professional valuation is a challenge that can lead to changes in the profession's image, towards a socially acknowledged profession, whose care practice is improved and guided by knowledge resulting from scientific research(10).

Other factors still need to be defeated, such as the low level of interdisciplinarity and practically inexist multiprofessional nature in the composition of NERG from the South, with the almost exclusive predominance of nurses ${ }^{(4-10)}$. Today, partnerships need to be established between different departments and knowledge area, strengthening the creation of networks and multicenter research, with different leaderships and possibilities for political and scientific articulation.

This discussion in not new in the Nursing area, as the Pan American Health Organization's Human Resource Policy, the results of conflicts during several Pan American colloquia or Ibero-American conferences, discussions led by the Latin American Association of Nursing Schools and Colleges (ALADEFE), CAPES Nursing assessment fora and other spaces show the intent to constitute collaborative networks in Nursing Education. The reinforcement of the technological sector in Nursing Education lacks integration of interests with supportive goals, based on the development of collective networks, union and the strengthening of Nursing intellectuals, which could result, for example, in patented technological products to strengthen their research lines.

The comparative analysis of Doctoral education in Nursing in Brazil, Europe and North America, for example, shows that they are based on the same premises, but that the need for interlocution between different colleges, service deliverers, industries and researchers still continues with a view to the constitution of an international network ${ }^{(9)}$. In Brazilian graduate Nursing programs, particularly the supply of Nursing Ph.D's has grown significantly in recent years, gaining visibility in the country's higher education system. Unfortunately, this growth is unequal among different Brazilian regions, and this inequality is also reflected in research activity initiatives in partnership with international researchers - collaborative networks - as they exist but are still timid and limited to some strongly consolidated graduate programs, mainly in the Southeast of Brazil(8). In this respect, the Nursing Education sector in the South of Brazil underlines the findings in the Brazilian Nursing area.

Based on the context of interest in international visibility, graduate programs in Nursing have increased the level of demand on their researchers in terms of their products' quality and quantity, following the trend towards international competitiveness. Differently from international reality, in which many institutions hire Ph.D. researchers to serve exclusively as researchers, in Brazil, 
the policy of indissociability between teaching, research and community service reflects the dissonance in the scenario of scientific/technological production versus teaching. In this panorama, some bottlenecks should be highlighted, such as faculty members' great investments of time and interest in the research area, to the detriment of teaching. Thus, often, research remains a priority when compared with teaching quality. When the educational base disappears though, the contents of integration and social and economic insertion is $\operatorname{lost}^{(7)}$.

In this scenario, even nursing professionals in graduate programs get involved in a complex problem, considering the need for quantity and quality in their academic production while maintaining their institutional functions. These programs' teaching axis is the preparation of researchers, as a space to legitimize nurses' knowledge and intellectual work, receiving recognition and prestige which they probably did not fin in care work ${ }^{(11)}$, due to some historical determinants of the profession. Due to ambivalent pressure, advisors indicate their preference for younger students with previous experience in a scientific initiation grant, while Master's and Doctoral students feel pressured to deliver high-quality products and reach targets, demanding teachers' greater availability ${ }^{(11)}$.

Thus, productivity has become an expression of scientific progress, but freedom is needed for productivity to occur. For creation, renewal and innovation, according to their own rhythm, researchers need to advance in the creation process and not see themselves as competing machines obsessed with goals achievement ${ }^{(7)}$. The lack of patented technological products by NERG in the South indicates the need to advance in this process with a view to continuing knowledge development. Keeping up originality becomes difficult amidst the progressive bureaucratization of science and, precisely because of this, based on this analysis, it is vital for members of different NERG to join efforts ${ }^{(4)}$.

The NERG's work is fundamental with a view to the availability of infrastructure to aggregate researchers and members in research activities, permitting integrated work and increased research potential(5). The composition of NERG in the South of Brazil, however, remains distant from the multiprofessional, interdisciplinary and network articulation process with a view to research development, as its publications and composition almost totally come from nurses working in specific foci(4).

Despite all difficulties described above, the NERG are moving ahead slowly but progressively for the sake of technological and scientific advances. Fortunately book production is not considered obsolete for the health sector yet, although it is less traditional than it other more specific areas like social and human sciences. In this respect, the inversion in NERG's book or book chapter production, when compared with the growth in their scientific paper production, can be explained, among other factors, by the fact that international scientific consumption in health is directed at short and objective papers, saving clinical professionals' time to apprehend new and updated knowledge.

Efforts by CAPES and the Ministry of Education should be highlighted, aimed at including researchers in the process of achieving greater autonomy and international acknowledgement in the research sector. One example is the CAPES Portal of Journals, which represents an important financial investment, permitting access to fulltext databases. For many teaching institutions, this access is restricted though, limiting the internationalization process of the Nursing Education sector in the South of Brazil and arousing discussions about knowledge production as a tradable or public good.

Novelty comes in at a high speed and aggressively hits all sectors, and this is no different for the NERG. In this sense, the Brazilian policy of science and technology shows its cruelty and generates inequities: the most productive institutions receive more funding; the least productive institutions with a worse CAPES assessment receive little or no funding, less scientific grants for undergraduate and graduate students and faculty members-researchers themselves. This policy generates a vicious circle that does not contribute at all to overcome this scenario, with a view to allowing for the equitable strengthening of scientific institutions. The encouragement of patent development, for example, is a strong sign of the market's imperative presence, even in the academic sector which, in the dominant capitalist world, awakens inequality with a new name: intellectual inequality.

\section{Conclusions}

The Nursing Education sector in the South of Brazil shows progressive growth in science and technology in the last five years when compared with data for the 1990's. The sector still needs significant advances though, so as to contribute for the nursing area to reach other health areas' scientific production parameters. For this structure to be strengthened, the constitution of collaborative networks can be used as a strategy to develop scientific research, expanding production directed at social needs, disseminated in preferably international and qualified 
journals, as well as the development of new educational technologies. This is a viable alternative, in view of nursing researchers' high qualification, whose political-scientific articulation with other social groups could result in referral centers in the South of Brazil.

Like any scientific study, this research also demands more in-depth analyses, through subsequent projects which the researchers are developing on the following themes: 1) assessment of NERG's scientific and technological production trends in the South of Brazil, highlighting what references have been most published and evidencing the disciplines and sub-disciplines disseminated in scientific papers, also from a geographical analysis perspective and 2) further elaborate the relation between the NERG's technological-scientific production, in correlation with regional inequities in Brazil.

\section{References}

1. Erdmann $A L$, Silva IA, Rodrigues RAP, Fernandes JD, Vianna LAC, Lopes MJM, et al. Nursing doctoral theses produced on Graduate Programs between 1983-2001. Rev Esc Enferm USP 2005; 39(Esp.):497-505.

2. Albuquerque EM, Simões $R$, Baessa $A$, Campolina $B$, Silva L. A distribuição espacial da produção científica e tecnológica brasileira: uma descrição de estatísticas de produção local de patentes e artigos científicos. Rev Bras Inovação 2002 jul-dez; $1(2): 225-51$

3. Nietsche EA, Backes VMS, Colomé CLM, Ceratti RN, Ferraz F. Education, care and management technologies: a reflection based on nursing teachers' conception. Rev. Latino-Am. Enfermagem. 2005; 13(3):344-53.

4. Backes VMS, Canever BP, Ferraz F, Lino MM, Prado ML, Reibnitz KS. Research Groups in Nursing in the South Region part of Brazil. Rev Gaúch Enferm 2009 jun; 30(2): in press.

5. Erdmann AL, Lanzoni GMM. Research group characteristics of the Brazilian Nursing certificated by the CNPq from 2005 to 2007. Esc Anna Nery Rev Enferm. 2008 jun; 12(2):316-22.
6. Coordenação de Aperfeiçoamento de Pessoal de Nível Superior - CAPES. História e missão. [acesso em: 16 fev 2009]. Disponível em: http://www.capes.gov.br/sobre-a-capes/historia-e-missao. 7. Luz MT. Prometheus bound: a sociological analysis of the category productivity and current conditions in academic life. PHYSIS: Rev Saúde Colet 2005; 15(1):39-57.

8. Rodrigues RP, Erdmann AL, Silva IA, Fernandes JD, Santos RS, Araújo TL. Nursing doctoral education in Brasil. Texto Contexto Enferm maio 2002; 11(3):66-76.

9. Rodrigues RAP, Erdmann AL, Silva IA, Fernandes JD, Araújo $T L$, Vianna LAC, et al. Doctoral Education in Nursing in Brazil. Rev. Latino-Am. Enfermagem. 2008 jul; 16(4):665-71.

10. Roese A, Souza AC, Porto GB, Colomé ICS, Costa LED. The production of knowledge on Nursing: challenges in the search of recognition in the interdisciplinary field. Rev Gaúch Enferm. Dez 2005; 26(3):302-7.

11. Bujdoso YLV, Cohn A. University as coping for dealing with care work of Nursing Master's students. Rev Saúde Pública. 2008; 42(2):273-8. 